\title{
MODUL LITERASI SAINS BERBASIS PEMBELAJARAN DARING MATERI EKOSISTEM UNTUK SISWA KELAS V SEKOLAH DASAR
}

\author{
Soya Pramesti Shahida ${ }^{1}$, Arifin Maksum ${ }^{2}$, A. R. Supriatna ${ }^{3}$ \\ Fakultas Ilmu Pendidikan, Universitas Negeri Jakarta \\ e-mail: soyapramesti01@gmail.com
}

\begin{abstract}
ABSTRAK
Penelitian ini bertujuan untuk menghasilkan modul literasi sains berbasis pembelajaran daring pada muatan IPA materi ekosistem untuk siswa kelas V sekolah dasar. Modul literasi sains tersebut untuk memudahkan siswa dalam pembelajaran daring pada materi ekosistem. Penelitian pengembangan ini menggunakan metode Research and Development (R\&D) dengan mengacu pada model ADDIE dengan tahapan pengembangan sebagai berikut: (1) Analisis; (2) Desain; (3) Pengembangan; (4) Implementasi; dan (5) Evaluasi. Subjek uji coba dalam penelitian pengembangan ini adalah subjek ahli, yaitu ahli materi, ahli bahasa, dan ahli media, serta peserta didik kelas $\mathrm{V}$ sekolah dasar sebagai calon pengguna produk. Teknik pengumpulan data dilakukan dengan angket. Hasil penelitian menunjukkan bahwa modul literasi sains berbasis pembelajaran daring pada muatan IPA materi ekosistem untuk siswa kelas $\mathrm{V}$ sekolah dasar memperoleh presentase sebesar 91\% dari ahli materi, $86 \%$ dari ahli bahasa, dan $84 \%$ dari ahli media dengan masing-masing kategori "sangat layak". Hasil uji coba pengguna pada siswa memperoleh keseluruhan rata-rata sebesar 93\% dengan kategori "sangat menarik". Maka dapat disimpulkan bahwa modul literasi sains berbasis pembelajaran daring pada muatan IPA materi ekosistem ini sangat layak digunakan dalam kegiatan pembelajaran daring dan menarik bagi siswa.
\end{abstract}

Kata Kunci: literasi sains, berbasis pembelajaran daring, ekosistem

\section{ABSTRACT}

This study aims to produce a scientific literacy module based on online learning on the science content of ecosystem materials for fifth grade elementary school students. The scientific literacy module is to facilitate students in online learning on ecosystem materials. This development research uses themethod Research and Development (R\&D) with reference to the ADDIE model with the following development stages: (1) Analysis; (2) Design; (3) Development; (4) Implementation; and (5) Evaluation. The test subjects in this development research are expert subjects, namely material experts, linguists, and media experts, as well as fifth grade elementary school students as potential users of the product. The technique of data collection is done by questionnaire. The results showed that the scientific literacy module based on online learning on the content of ecosystem materials for fifth grade elementary school students obtained a percentage of $91 \%$ from material experts, $86 \%$ from linguists, and $84 \%$ from media experts with each category "very feasible". The results of user trials on students obtained an overall average of $93 \%$ in the "very interesting" category. So it can be 
concluded that the scientific literacy module based on online learning on the science content of ecosystem material is very suitable for use in online learning activities and is interesting for students.

\section{Keywords: scientific literacy, online learning-based, ecosystem}

\section{PENDAHULUAN}

Pendidikan di Indonesia mengalami perubahan akibat pandemi Covid-19, kegiatan pembelajaran saat ini dilakukan secara daring. Guru dan siswa yang terbiasa bertatap muka secara langsung dalam proses pembelajaran, sekarang berada pada situasi di mana mereka harus melakukan kegiatan pembelajaran secara daring tanpa adanya persiapan sebelumnya (Putria, Maula, \& Uswatun, 2020:862). Pembelajaran daring merupakan kegiatan pembelajaran yang menggunakan berbagai platform digital sebagai sarana untuk menyampaikan materi pembelajaran (Handarini \& Wulandari, 2020:498). Dalam menghadapi Covid-19, guru dan peserta didik perlu beradaptasi dengan platform yang dapat mendukung pembelajaran daring seperti zoom, google meet, dan sebagainya sebagai tanda transfer kegiatan pembelajaran yang positif. Pada kondisi di tengah pandemi Covid-19, telah banyak mengalami berbagai perubahan dan pentingnya untuk memiliki sikap ilmiah, yaitu sikap yang memiliki kemampuan dan pemahaman tentang ilmu pengetahuan dengan baik untuk memenuhi tuntutan perkembangan zaman. Pada jenjang sekolah dasar Ilmu Pengetahuan Alam atau sains merupakan pelajaran yang berperan penting dalam pendidikan karena sains dapat menjadi bekal bagi siswa dalam menghadapi berbagai tantangan sesuai perkembangan zaman (Ridho, Putri, and Purworejo 2019:403). Siswa membutuhkan objek belajar yang konkret dalam mengikuti proses pembelajaran agar dapat mengatasi permasalahan dalam kehidupan sehari-hari.

Kegiatan pembelajaran yang dilakukan secara daring juga memerlukan media pembelajaran sebagai sumber belajar yang sesuai dengan kondisi pandemi saat ini. Media pembelajaran merupakan sarana penyampaian materi yang digunakan untuk berinteraksi secara dua arah dalam proses pembelajaran (Suparlan, 2020:182). Pentingnya meningkatkan kualitas sumber belajar sebagai bentuk peningkatan mutu pembelajaran dan meninjau keberhasilan peserta didik dalam menimba ilmu di sekolah. Modul pembelajaran mempunyai peran penting dalam proses kegiatan pembelajaran. Walaupun perkembangan buku digital yang semakin pesat, namun modul pembelajaran sampai saat ini tetap menjadi pegangan guru.

Berdasarkan hasil wawancara dengan siswa kelas V SDN Jatinegara Kaum 01, diperoleh informasi bahwa siswa mengalami kesulitan dalam pelajaran pada muatan IPA materi ekosistem yang dirasa cukup sulit dipahami dan membutuhkan media pembelajaran lain untuk membantu mereka dalam memahami materi. Hasil dari wawancara bersama dengan guru kelas V SDN Jatinegara Kaum 01, diperoleh informasi bahwa diperlukan media pembelajaran lain yang tidak banyak menghabiskan terlalu banyak kuota internet di masa pandemi ini. Data PISA (Programe for International Student Assessment) juga menunjukkan kemampuan literasi sains peserta didik di Indonesia masih rendah. Literasi sains yang masih rendah dapat menyebabkan peserta didik menjadi tidak kompetitif karena kurangnya 
kecakapan ilmu pengetahuan (Teguh, 2017:19). Peserta didik dapat meningkatkan kemampuan literasi dan potensi yang dimiliki seutuhnya jika pendidik mampu mengembangkan pembelajaran yang tepat dan sesuai. Hasil PISA 2018 untuk kompetensi sains, Indonesia menempati peringkat 62 dari 71 negara peserta. Dalam hal literasi sains, secara nasional baru $25.38 \%$ literasi sains yang dinilai cukup, sementara $73 \%$ dinyatakan kurang (Narut \& Supradi, 2019:65). Hasil observasi yang dilakukan oleh peneliti, menunjukkan beberapa masalah yang muncul saat pembelajaran IPA, yaitu saat proses pembelajaran peserta didik kurang berperan aktif dan kesulitan siswa dalam memahami materi ekosistem. Ekosistem adalah hubungan antara makhluk hidup dan benda tak hidup di sebuah lingkungan (Nurdiansyah, dan Amalia, 2018:5), dalam hal ini materi yang cukup dekat dengan lingkungan dan kehidupan sehari-hari.

Permasalahan lingkungan saat ini tidak hanya karena globalisasi tetapi juga dampak merebaknya pandemi Covid-19 seperti sampah masker dan sarung tangan karet yang banyak terbuang ke laut mengakibatkan pencemaran ekosistem air dan menjadi makanan hewanhewan laut, dan perubahan suhu yang mengakibatkan curah hujan yang tinggi serta adanya penebangan pohon sembarangan yang terjadi di daerah dataran tinggi yang menyebabkan longsor dan banjir (Rifa'i, I., Irwansyah, F. S., Sholihah, M. A., \& Yuliawati, 2020). Pengembangan literasi sains meliputi pengetahuan alam, proses menumbuhkan sikap ilmiah terhadap peserta didik agar mampu menerapkan kemampuan sains dalam menghadapi abad 21 (Pratiwi, Cari, \& Aminah, 2019:35). Pentingnya siswa untuk memiliki kesadaran dan kepedulian yang tinggi terhadap lingkungan khususnya ekosistem agar tidak lagi kehilangan ekosistem penting akibat dari kerusakan lingkungan (Lestari, 2018:333).

Literasi sains diartikan sebagai kemampuan seseorang dalam memahami dan mengkomunikasikan sains dalam bentuk lisan dan tulisan dalam memcahkan masalah menggunakan pandangan-pandangan sains (Arlis et al., 2020:3). Pengetahuan yang dimiliki seseorang mengenai masalah-masalah yang berkaitan dengan lingkungan sehingga dapat memcahkan masalah dengan bukti-bukti ilmiah yang akhirnya memiliki sikap ilmiah dan kesadaran yang tinggi terhadap lingkungan. Menurut PISA, ada 4 dimensi besar pada literasi sains, yaitu konten sains, proses sains, implementasi sains, dan sikap (Narut \& Supradi, 2019:64). Dimensi-dimensi pada literasi sains harus berkaitan satu dengan lainnya, harus saling berkelanjutan dari konten sains hingga sikap ilmiah.

Penelitian ini relevan dengan penelitian yang dilakukan oleh Aris Sunandar dengan judul penelitian "Pengembangan Bahan Ajar Modul Berbasis Literasi Sains Model ADDIE Pada Pokok Bahasan Ekosistem" peneliti mengembangkan bahan ajar modul berbasis literasi sains yang digunakan oleh peserta didik kelas X Sekolah Menengan Atas (SMA). Perbedaan yang ditemukan terdapat pada jenjang pendidikan dan berbasisnya. Modul yang dikembangkan pada penelitian ini adalah modul literasi sains berbasis pembelajaran daring yang dirancang untuk peserta didik kelas V Sekolah Dasar (SD).

Berdasarkan permasalahan tersebut, peneliti tertarik untuk melakukan penelitian pengembangan modul literasi sains berbasis pembelajaran daring pada muatan IPA materi ekosistem yang bertujuan untuk dapat memudahkan siswa dalam memahami materi yang dirasa cukup sulit. Pemilihan pelajaran IPA dipilih karena IPA adalah pembelajaran yang 
diperoleh secara mandiri dengan menggunakan metode untuk membuat sebuah perspektif baru yang berfokus pada proses ilmiah yang bersifat sistematis (Kumala, 2016:8). Menurut (Kristyowati \& Purwanto, 2019:185) IPA atau sains dengan menerapkan literasi sains mempunyai peran penting dalam kehidupan sehari-hari yang merupakan salah satu pelajaran yang melibatkan aktivitas fisik dalam pembelajaran.

Hasil penelitian ini diharapkan memberikan manfaat untuk berbagai pihak, sebagai berikut: (1) Bagi guru: hasil penelitian ini dapat membantu dalam kegiatan pembelajaran untuk meningkatkan literasi peserta didik, menambah wawasan dan pengalaman mengenai literasi sains; (2) Bagi siswa: hasil penelitian ini dapat membantu memahami materi ekosistem dengan menerapkan literasi pada modul, memberikan suasana belajar yang berbeda karena setiap peserta didik memiliki gaya belajar yang berbeda, dan memberikan motivasi kepada peserta didik agar lebih berperan aktif dalam belajar serta mengembangkan kemampuan peserta didik; (3) Bagi sekolah: hasil penelitian ini dapat memfasilitasi agar prestasi peserta didik meningkat dan memiliki motivasi belajar yang tinggi serta dapat mengembangkan potensi, minat dan kebutuhan peserta didik.

\section{METODE}

Jenis penelitian yang digunakan pada penelitian ini adalan Research and Development (R\&D) dengan model ADDIE (Ibrahim et al., 2018:152). Penelitian dan pengembangan Research and Development (R\&D) bertujuan untuk menghasilkan produk yang berguna untuk meningkatkan kualitas pendidikan (Dwi \& Purwokerto, 2019:5). Berbagai bentuk pengembangan baik model, media, pendekatan atau metode pembelajaran harus bersifat efektif dan efisien yang dapat menunjang kompetensi peserta didik dan produk yang dihasilkan perlu melewati validasi dan beberapa uji coba agar dapat dipertanggung jawabkan.

Menurut (Kustandi \& Darmawan, 2020:104-105), kelima tahap pada model ADDIE perlu dilakukan secara sistematik dengan tahap-tahap sebagai berikut. Tahap pertama Analyze (Analisis), kegiatan pada tahap ini melakukan analisis kebutuhan untuk menentukan potensi yang harus dimiliki siswa untuk meningkatkan prestasi belajar dan melakukan analisis kinerja untuk mengidentifikasi masalah yang muncul serta mencari solusi yang harus dilakukan sesuai hasil analisis kebutuhan. Kedua, tahap Design (Perencanaan), tahap merancang desain pembelajaran atau merumuskan materi yaitu materi ekosistem sesuai dengan hasil analisis kebutuhan yang diperoleh agar dapat membuat peserta didik memiliki pengalaman belajar dan dapat mengatasi kesenjangan yang terjadi pada peserta didik, menentukan strategi pembelajaran sesuai tujuan pembelajaran, dan mulai merancang produk yang akan dikembangkan. Tahap ketiga, Development (Pengembangan), tahap merealisasikan rancangan produk. Pada tahap ini, produk yang dikembangkan berbentuk konseptual direalisasikan dan siap untuk diimplementasikan. Pengembangan produk ini akan melalui tahap validasi oleh tiga expert review yaitu, ahli materi, ahli bahasa, dan ahli media. Penilaian pada produk yang dikembangkan menggunakan instrumen penelitian dalam bentuk angket (Alhamid \& Anufia, 2016:2). Bertujuan untuk memperoleh masukkan serta saran agar produk menjadi lebih baik dan layak digunakan dalam pembelajaran, setelah itu produk akan melalui tahap selanjutnya. Implementation (Implementasi), tahap implementasi yaitu melakukan uji coba one-to-one, small group dan field test yang dilakukan secara pembelajaran daring dengan siswa, 
bertujuan untuk mengetahui produk yang dikembangkan dapat mengatasi kesenjangan peserta didik, membantu peserta didik dalam memahami materi, dan produk yang dikembangkan oleh peneliti menarik dan layak digunakan sebagai salah satu sumber belajar dalam kegiatan pembelajaran. Tahap terakhir, Evaluation (Evaluasi), kegiatan yang dilakukan setelah melakukan uji coba bersama peserta didik yaitu tahap evaluasi, siswa mengevaluasi produk dengan menggunakan angket untuk meninjau kelayakan dan kemenarikan produk yang dikembangkan. Penelitian ini dilakukan disalah satu sekolah dasar daerah Bogor tepatnya di SDN Kaumpandak 02, dilaksanakan pada bulan Juni-Juli 2021 dengan uji coba one-to-one yang dilakukan bersama 3 siswa, uji coba small group dengan 5 siswa, dan uji coba field test dengan 23 siswa. . Teknik pengumpulan data dalam penelitian ini menggunakan wawancara dan angket.

Penelitian dan pengembangan ini menggunakan teknik analisi data dekriptif dengan menggunakan skala likert yang dianalisis dengan teknik persentase (Pranatawijaya \& Priskila, 2019:132). Pemberian skor pada hasil penilaian masing-masing subjek sebagai berikut.

Tabel 1. Pemberian Skor

\begin{tabular}{|c|c|}
\hline Keterangan & Skor \\
\hline Sangat Layak & 5 \\
\hline Layak & 4 \\
\hline Cukup Layak & 3 \\
\hline Tidak Layak & 2 \\
\hline Sangat Tidak Layak & 1 \\
\hline
\end{tabular}

Skor yang telah diperoleh dihitung sesuai dengan pernyataan yang dipilih oleh expert review, kemudian dihitung dengan rumus:

$$
\frac{\sum \text { Jumlah Skor Hasil Penilaian }}{\sum \text { Jumlah Skor Maksimum }} \times 100 \%
$$

Nilai yang diperoleh dari rumus akan dideskripsikan dengan melihat persentase kelayakan produk dari hasil penilaian.

Tabel 2. Kriteria Kelayakan

\begin{tabular}{|c|c|}
\hline Persentase (\%) & Kategori \\
\hline $81 \%-100 \%$ & Sangat Layak \\
\hline $61 \%-80 \%$ & Layak \\
\hline $41 \%-60 \%$ & Cukup Layak \\
\hline $21 \%-40 \%$ & Tidak Layak \\
\hline $0 \%-20 \%$ & Sangat Tidak Layak \\
\hline
\end{tabular}

Nilai atau skor yang diperoleh dari peserta didik dihitung dengan rumus yang sama seperti expert review dan akan dideskripsikan dengan melihat kemenarikan produk dilihat dari kategori intreprestasi skor. 
Tabel 3. Kriteria Interprestasi Skor

\begin{tabular}{|c|c|}
\hline Persentase (\%) & Kategori \\
\hline $81 \%-100 \%$ & Sangat Baik \\
\hline $61 \%-80 \%$ & Baik \\
\hline $41 \%-60 \%$ & Cukup Baik \\
\hline $21 \%-40 \%$ & Kurang Baik \\
\hline $0 \%-20 \%$ & Sangat Kurang Baik \\
\hline
\end{tabular}

Tabel kriterian kelayakan dan kemenarikan menunjukkan semakin tinggi nilainya maka persentase kategori yang diperoleh juga semakin baik.

\section{HASIL DAN PEMBAHASAN}

Modul literasi sains berbasis pembelajaran daring adalah media pembelajaran yang dikembangkan oleh peneliti sebagai pendukung atau fasilitator siswa dalam belajar. Penelitian dan pengembangan pada modul literasi sains berbasis pembelajaran daring pada materi ekosistem yang telah selesai didesain akan divalidasi oleh tiga expert review yaitu, ahli materi, ahli bahasa, ahli media dan melakukan uji coba dengan siswa kelas V sekolah dasar. Berikut merupakan hasil validasi tiga expert review yang ranah dalam mengajarnya berhubungan dengan yang peneliti butuhkan.

Tabel 4. Hasil Validasi Ahli Materi

\begin{tabular}{|c|c|c|c|c|}
\hline Aspek & $\begin{array}{c}\text { Jumlah } \\
\text { Peraspek }\end{array}$ & $\begin{array}{c}\text { Jumlah Skor } \\
\text { Maksimum }\end{array}$ & $\begin{array}{c}\text { Skor } \\
\text { Diperoleh }\end{array}$ & Persentase \\
\hline Isi materi & 14 & 70 & 63 & \multirow{2}{*}{$91 \%$} \\
\cline { 1 - 3 } $\begin{array}{c}\text { Penyajian } \\
\text { materi }\end{array}$ & 4 & 20 & 19 & \\
\cline { 1 - 3 } Bahasa & 2 & 10 & 9 & \\
\hline Jumlah & 20 & 100 & 91 & \\
\hline
\end{tabular}

Hasil perhitungan $=\frac{91}{100} \times 100 \%=91 \%$

Berdasarkan perhitungan skor di atas, hasil memperoleh presentasi sebesar $91 \%$ dengan kategori Sangat Layak. 
Tabel 5. Hasil Validasi Ahli Bahasa

\begin{tabular}{|c|c|c|c|c|}
\hline Aspek & $\begin{array}{c}\text { Jumlah } \\
\text { Peraspek }\end{array}$ & $\begin{array}{c}\text { Jumlah Skor } \\
\text { Maksimum }\end{array}$ & $\begin{array}{c}\text { Skor } \\
\text { Diperoleh }\end{array}$ & Persentase \\
\hline $\begin{array}{c}\text { Sesuai dengan } \\
\text { perkembangan peserta } \\
\text { didik }\end{array}$ & 2 & 10 & 8 & \multirow{2}{*}{$86 \%$} \\
\hline Interaktif dan dialogis & 2 & 10 & 10 & \\
\hline Lugas & 3 & 15 & 12 & \\
\hline $\begin{array}{c}\text { Keterpaduan alur } \\
\text { materi }\end{array}$ & 1 & 5 & 4 & \\
\hline $\begin{array}{c}\text { Penggunaan simbol } \\
\text { dan istilah }\end{array}$ & 2 & 10 & 9 & \\
\hline Jumlah & 10 & 50 & 43 & \\
\hline
\end{tabular}

Hasil perhitungan $=\frac{43}{50} \times 100 \%=86 \%$

Berdasarkan perhitungan skor di atas, hasil memperoleh presentasi sebesar $86 \%$ dengan kategori Sangat Layak.

Tabel 6. Hasil Validasi Ahli Media

\begin{tabular}{|c|c|c|c|c|}
\hline Aspek & $\begin{array}{c}\text { Jumlah } \\
\text { Peraspek }\end{array}$ & $\begin{array}{c}\text { Jumlah Skor } \\
\text { Maksimum }\end{array}$ & $\begin{array}{c}\text { Skor } \\
\text { Diperoleh }\end{array}$ & Persentase \\
\hline $\begin{array}{c}\text { Ukuran pada } \\
\text { modul }\end{array}$ & 12 & 60 & 51 & \multirow{2}{*}{$84 \%$} \\
\cline { 1 - 3 } Desain modul & 8 & 40 & 33 & \\
\hline Jumlah & 20 & 100 & 84 & \\
\hline
\end{tabular}

Hasil perhitungan $=\frac{84}{100} \times 100 \%=86 \%$

Berdasarkan perhitungan skor di atas, hasil memperoleh presentasi sebesar $84 \%$ dengan kategori Sangat Layak.

Tabel 7. Hasil Rekapitulasi Uji Coba Ahli (Expert Review)

\begin{tabular}{|c|c|c|}
\hline Responden & Presentase & \multirow{2}{*}{ Kategori } \\
\cline { 1 - 2 } Ahli Materi & $91 \%$ & \\
\cline { 1 - 2 } Ahli Bahasa & $86 \%$ & \multirow{2}{*}{ Sangat Layak } \\
\cline { 1 - 2 } Ahli Media & $84 \%$ & \\
\hline Rata-rata keseluruhan & $87 \%$ & \\
\hline
\end{tabular}


Hasil penliaian dari uji coba ahli (expert review) terhadap produk modul literasi sains berbasis pembelajaran daring pada muatan IPA materi ekosistem untuk siswa kelas V sekolah dasar menunjukkan presentase rata-rata keseluruhan $87 \%$ dengan memperoleh kategori Sangat Layak.

Tabel 8. Hasil Rekapitulasi Uji Coba Produk

\begin{tabular}{|c|c|c|c|}
\hline No & Uji Coba Produk & Presentase & Kategori \\
\hline 1. & One to One Evaluation & $91 \%$ & \\
\cline { 1 - 3 } 2. & Small Group Evaluation & $93 \%$ & \multirow{3}{*}{ Sangat Baik } \\
\cline { 1 - 3 } 3. & Field Test Evaluation & $96 \%$ & \\
\cline { 1 - 3 } & Rata-rata keseluruhan & $93 \%$ & \\
\hline
\end{tabular}

Berdasarkan perhitungan skor di atas, hasil memperoleh rata-rata keseluruhan persentase sebesar 93\% dengan kategori Sangat Baik. Hasil penliaian dari uji coba bersama peserta didik terhadap produk modul literasi sains berbasis pembelajaran daring pada muatan IPA materi ekosistem untuk siswa kelas V sekolah dasar menunjukkan presentase rata-rata keseluruhan $93 \%$ dengan memperoleh kategori sangat baik.

Dengan demikian, meskipun ada perbedaan presentase penilaian yang tidak terlalu signifikan antara ahli (expert review) dan siswa, maka dapat disimpulkan secara garis besar bahwa modul literasi sains sangat layak dan sangat baik bagi peserta didik untuk digunakan dalam kegiatan pembelajaran daring.

Modul literasi sains berbasis pembelajaran dari adalah media pembelajaran yang dikembangkan sebagai pendukung atau fasilitator peserta didik dalam belajar. Pengembangan ini bertujuan untuk mengembangkan modul dengan menerapkan literasi sains dalam pembelajaran IPA di sekolah dasar pada materi ekosistem. Sistematika modul literasi sains berbasis pembelajaran daring pada materi ekosistem dikembangkan peneliti dengan menyajikan secara berurutan bagian awal, isi dan penutup. Pada bagian awal modul terdiri dari cover, prakata, petunjuk penggunaan modul, kompetensi inti, kompetensi dasar, tujuan pembelajaran dan pendahuluan. Bagian isi terdiri dari uraian materi, latihan soal dan evaluasi untuk melihat ketercapaian tujuan pembelajaran yang berada disetiap awal materi. Terakhir bagian penutup terdiri dari teks bercerita yang berkaitan dengan ekosistem, glosarium, dan daftar pustaka. Modul terdiri dari tiga bab, yaitu: (1) Ekosistem; (2) Pola Interaksi Ekosistem; (3) Aliran Energi Dalam Ekosistem. Jumlah seluruh halaman pada modul adalah 101 halaman, jika dihitung dengan isi dari bagian awal modul, keseluruhan jumlah halaman adalah 111 halaman.

Penyusunan modul IPA disusun dengan menerapkan literasi sains sebagai pemenuh kebutuhan dan sesuai dengan standar mutu pembelajaran yang sudah selaras dengan pembelajaran abad 21, yang diharapkan dapat membantu peserta didik dalam membentuk pola pikir serta memiliki sikap ilmiah yang dapat peduli dan bertanggung jawab untuk diri sendiri, masyarakat sekitar, dan lingkungan (Pratiwi et al., 2019:35).

Modul literasi sains berbasis pembelajaran daring pada materi ekosistem sudah melalui tahap-tahap validasi oleh ahli materi, ahli bahasa, dan ahli media serta telah melakukan perbaikan sesuai masukkan dan saran dari para ahli atau validator dengan 
memperoleh sangat layak sehingga modul literasi sains yang dikembangkan peneliti layak untuk digunakan dalam kegiatan pembelajaran daring.

Berdasarkan hasil yang diperoleh peneliti pada uji coba one-to-one, small group, dan field test yang dilakukan bersama siswa kelas V sekolah dasar, modul literasi sains berbasis pembelajaran daring memperoleh hasil dengan kategori sangat menarik. Kemenarikan modul disebabkan penerapan literasi sains yang dibuat agar siswa menjadi lebih aktif dan memilki rasa keingintahuan yang tinggi untuk memperoleh informasi pada materi ekosistem yang dikaitkan dengan kehidupan sehari-hari (Situmorang, 2016:52). Materi yang berkaitan dengan kehidupan sehari-hari serta ilustrasi dan gambar yang melengkapi modul menimbulkan kemenarikan bagi peserta didik menjadi lebih minat dan termotivasi untuk mempelajari modul, sehingga secara tidak langusng dapat membuat peserta didik lebih memahami materi yang dipelajari dan tidak membuat peserta didik jenuh atau bosan saat menggunakan modul.

\section{PENUTUP}

Penelitian dan pengembangan ini menghasilkan produk modul literasi sains berbasis pembelajaran daring pada muatan IPA materi ekosistem untuk siswa kelas V sekolah dasar. Pengembangan modul telah mengikuti tahap-tahap pengembangan pada model ADDIE, serta telah divalidasi oleh tiga expert review yaitu ahli materi, ahli bahasa, dan ahli media dengan memperoleh rata-rata presentase sebesar $87 \%$ dengan kriteria sangat layak dan sudah melakukan tahap evaluasi dengan uji coba pada peserta didik dengan memperoleh presentase sebesar 93\% dengan kriteria sangat baik. Maka dapat disimpulkan bahwa modul literasi sains berbasis pembelajaran daring pada materi ekosistem adalah sangat layak digunakan dalam kegiatan pembelajaran daring dan sangat menarik bagi siswa.

\section{UCAPAN TERIMA KASIH}

Peneliti mengucapkan terima kasih kepada dosen pembimbing dan kepada para dosen ahli yang telah bersedia untuk memberikan penilaian terhadap kelayakan produk pengembangan. Kepada Kepala Sekolah dan Guru yang telah mengizinkan peneliti melakukan penelitian di SDN Kaumpandak 02 serta kepada siswa yang telah bersedia menjadi objek penelitian.

\section{DAFTAR PUSTAKA}

Alhamid, T., \& Anufia, B. (2016). Instrumen Pengumpulan Data. 4(1), 64-75.

Arlis, S., Amerta, S., Indrawati, T., Zuryanty, Z., Chandra, C., Hendri, S., Kharisma, A., \& Fauziah, M. (2020). Literasi Sains Untuk Membangun Sikap Ilmiah Siswa Sekolah Dasar. Jurnal Cakrawala Pendas, 6(1), 0-14.

Dwi, A., \& Purwokerto, U. M. (2019). Research and Development: Penelitian yang Produktif Dalam Dunia Pendidikan. August.

Handarini, O. I., \& Wulandari, S. S. (2020). Pembelajaran Daring Sebagai Upaya Study From Home (SFH) Selama Pandemi Covid 19. Pendidikan Administrasi Perkantoran (JPAP), 8(3), 496-503.

Ibrahim, A., Alang, A. H., Madi, Baharudin, Ahmad, M. A., \& Darmawati. (2018). Metodologi Penelitian (I. Ismail (ed.)). Gunadarma Ilmu. 
Kristyowati, R., \& Purwanto, A. (2019). Pembelajaran Literasi Sains Melalui Pemanfaatan Lingkungan. Scholaria: Jurnal Pendidikan Dan Kebudayaan, 9(2), 183-191.

Kumala, F. N. (2016). Pembelajaran IPA SD. Ediide Infografika.

Kustandi, C., \& Darmawan, D. (2020). Pengembangan Media Pembelajaran.

Lestari, Y. (2018). Penanaman Nilai Peduli Lingkungan Dalam Pembelajaran Ilmu Pengetahuan Alam. Jurnal Pendidikan Ke-SD-An, 4(2), 332-337.

Narut, Y. F., \& Supradi, K. (2019). Literasi sains peserta didik dalam pembelajaran ipa di indonesia. Jurnal Inovasi Pendidikan Dasar, 3(1), 61-69.

Nurdiansyah, dan Amalia, F. (2018). Model Pembelajaran Berbasis Masalah Pada Pelajaran IPA Materi Komponen Ekosistem. Pgmi Umsida, 1, 1-8.

Pranatawijaya, V. H., \& Priskila, R. (2019). Pengembangan Aplikasi Kuesioner Survey Berbasis Web Menggunakan Skala Likert dan Guttman. 5(November), 128-137.

Pratiwi, S. N., Cari, C., \& Aminah, N. S. (2019). Pembelajaran IPA Abad 21 dengan Literasi Sains Siswa. Jurnal Materi Dan Pembelajaran Fisika (JMPF), 9(1), 34-42.

Putria, H., Maula, L. H., \& Uswatun, D. A. (2020). Analisis Proses pembelajaran Dalam Jaringan (DARING) Masa Pandemi COVID-19 pada Guru Sekolah Dasar. Jurnal Basicedu, 4(4), 861-872.

Ridho, C., Putri, R., \& Purworejo, U. M. (n.d.). Media Pembelajaran Ipa Berbasis Literasi Sains. 398-405.

Rifa'i, I., Irwansyah, F. S., Sholihah, M. A., \& Yuliawati, A. (2020). Dampak dan pencegahan wabah Covid-19: Perspektif Sains dan Islam -. Jurnal Lembaga Penelitian Dan Pengabdian Masyarakat (LP2M), 1-10.

Teguh, M. (2017). Gerakan Literasi Sekolah Dasar. Gerakan Literasi Sekolah Dasar, 2(1), $18-26$.

Situmorang, R. P. (2016). Integrasi Literasi Sains Peserta Didik Dalam Pembelajaran Sains. Satya Widya, 32(1), 49.

Suparlan, S. (2020). Peran Media dalam Pembeajaran di SD/MI. Islamika, 2(2), 298-311. 